\title{
Paradoxes of Mentoring An Ethnographic Study of a Mentoring Programme for Highly-educated Women with Migrant Backgrounds
}

\author{
By Tytti Steel, Anna-Maija Lämsä \& Marjut Jyrkinen
}

\begin{abstract}
This article explores paradoxes that emerge in the mentoring of highly-educated, female, foreign-born job-seekers in Finland. Theoretically, the study is linked to the growing body of research scrutinising the integration or discrimination of migrants in working life. It analyses cultural practices and ideas that are visible and affect the mentoring interaction. On a more practical level, the paper determines how the mentors and mentees experience the mentoring, and how intercultural mentoring could be improved in order to promote mentees' employment. The article is based on ethnography and 11 semi-structured interviews.

Two major paradoxes and their links to cultural meanings were identified: the over-emphasised focus on Finnish language (the language paradox), and the myth of the strong Finnish woman (the support paradox). These can be seen as having aspects of both cultural awareness and situation-specific awareness. Using situation-specific awareness, some mentors understood the best way forward was to break the rules of the mentoring programme and not to use Finnish in all communication. This enabled a more equal setting for professional discussions. In some rare cases, when the mentors did not use situation-specific awareness, a vicious circle emerged and mentees felt even worse about their abilities and working life opportunities. Similarly, although the myth of the strong Finnish woman can be an empowering and positive model for the mentee, it can have a negative impact on the mentor, enabling undercurrents in the mentoring discussions which can be experienced as harsh and even hostile. This, instead of encouraging and supporting, can result in the undermining and 'othering' of the mentee.
\end{abstract}

Keywords: ethnography, intercultural, mentoring, migrant women, paradox

Steel, Tytti, Anna-Maija Lämsä and Marjut Jyrkinen "Paradoxes of Mentoring: An Ethnographic Study of a Menotring Programme for Highly-educated Women with Migrant Backgrounds", Culture Unbound, Volume 11, issue 2, 2019: 275-297. Published by Linköping University Electronic Press: http://www.cultureunbound. ep.liu.se 


\section{Introduction}

The aim of this article is to explore paradoxes that emerge in the mentoring of highly-educated, female, foreign-born job-seekers in Finland. We are interested in how the mentors and mentees experience mentoring, and how intercultural mentoring could be improved in order to promote mentees' employment. The employment rate of migrants is usually lower than that of native people in Europe and North America (Petrovic 2015). In Finland, the employment rate of foreign-born women is approximately $56 \%$, thereby lower than the average employment rate of $69 \%$, the employment rate of foreign-born men $(71.2 \%)$, or that of women with a Finnish background (73.5\%) (Nieminen et al. 2015). The language skills needed in the new home country, 'foreign' qualifications, a lack of local work experience and social networks are all hindrances for foreign-born job-seekers (Ahmad 2005, Jaakkola \& Reuter 2007, Povrzanović Frykman 2012, Tarnanen \& Pöyhönen 2011, Wolanik Boström \& Öhlander 2011). In addition to the challenges of learning a new language and updating one's qualifications, prejudice, xenophobia and discrimination are also encountered in the labour market (e.g. Aalto, Larja \& Liebkind 2010). In the European context, immigrants who have obtained their higher education, skills and credentials abroad have been identified as a particularly vulnerable group in the labour market (Kyhä 2006, Petrovic 2015, Tuori 2009:43).

Previous research has indicated a lack of studies dealing specifically with the manner in which culture influences mentoring programmes and relationships (Kent et al. 2013). Theoretically, our study is linked to the growing body of research scrutinising the integration of or discrimination against migrants in working life. Often the emphasis has been on what foreign-born people should do differently in order to integrate (Tuori 2009). Recent reports have indicated that Finnish society has failed to improve the inclusion of its new citizens, as their employment rates are relatively low and racism is widespread (European Agency for Fundamental Rights 2018, OECD 2018). Previous research has indicated that in Finland there is a very strong link between language, nationality and identity, although the homogeneity of Finns is often exaggerated (e.g. Elmgren 2016, Knuuttila 1996). Highly skilled migrants perceive Finns as being a closed, homogenous group that values security, tradition and the status quo (Koskela 2013). This idea is in line with what, for instance, Homi K. Bhabha (1994) has written about how culture is often understood as a homogenised unit with clear boundaries. Different cultural units are the basis for the production of cultural meanings, for instance 'othering' and hierarchies. In line with Bhabha, our epistemological understanding of culture is that differences in interaction or customs are true in everyday life, but that in essence, culture is hybrid and complex. From this stance, the term intercultural mentoring (Osula \& Irvin 2009) can be criticised for highlighting differences instead of shared ambitions, qualities, and values linked to 
working life. Therefore, it is important to scrutinise mentoring as an interactive cultural practice without assuming that only the jobseeker or mentee has to adapt to the new socio-cultural context. Instead, in today's globalising work markets, organisations also need to be prepared to adapt to a diverse workforce, as typically assumed in the literature on mentoring (e.g. Casado-Lumbreras et al. 2011). At the same time, our understanding of mentoring is that it is a constructive learning process (e.g. Cooper 1993) that highlights the active role of the mentee (see more in the Ethnography section). In addition, we should pay attention to the cultural meanings of the Finnish language as these can be central to the success of mentoring. In this frame, we will explore which cultural practices and ideas are visible and affect the mentoring interaction.

Mentoring has been targeted towards unemployed, foreign-born women on a larger scale in North America, but is now increasingly being targeted towards this group in Europe (Petrovic 2015). For example, in Germany, the non-profit organisation Beramí has been providing a mentoring network for highly qualified, foreign-born women since 2005. Approximately 18 mentoring dyads have been formed annually in the Beramí programme so far. In Denmark, immigrant and refugee women have been targeted by the KVINFo Mentor Network which aims to help migrant women by building their social and professional network. Since 2002, over 6000 women have participated in more than 3000 mentoring partnerships in this Danish programme (Petrovic 2015, KVINFo 2017). KVINFo has acted as the model for wOMENTO, a mentoring programme established in 2012 by the Family Federation of Finland. The results of the wOMENTo programme have been encouraging: in 2012-2014, 37\% of the 60 mentees who took part in the programme found a job, $30 \%$ of whom obtained a job in the field of their own profession during the mentoring process (Family Federation of Finland 2017).

The mentoring programme studied in this article was based on the womento model, and its focus was on integration, improvement of language skills and enhancing employment among the mentees (Family Federation of Finland 2017). In the studied programme, the womento model (described in more detail in Kinnunen 2013) also accepted foreign-born women as mentors, whereas the original model only permitted women with a Finnish background to be mentors. The studied programme was organised by an anonymous non-governmental organisation (ngo) that provides several kinds of service to migrant women. Our research material consists of personal interviews, participant observations and the mentoring documents provided by the NGO. Both the mentees and the mentors in the observed programme were women. The aim of the interviews was to determine how the women perceived the programme and their own career prospects and opportunities, as well as to more extensively map out the views of the interviewees regarding Finnish working life. 
In the preliminary analysis of the field notes and the interviews, some issues arose that we interpreted as paradoxical. We assessed their importance as high and assumed that applying a paradox framework (outlined by Schad et al. 2016) would be a fruitful way of scrutinising the sources. The framework, which has theoretical roots in philosophy and psychology, aims to provide a deeper understanding of the constructs, relationships, and dynamics surrounding organisational tensions. The paradox framework allows us to make visible the controversial nature of mentoring for foreign-born women, because, despite good intentions, formal mentoring programmes for these women may be embedded with paradoxes which, in addition to enabling, may also constrain their job-seeking opportunities. This combination is in line with the aims of a paradox frame that scrutinises complexities rather than 'either-or' results (Schad et al. 2016). We seek to answer the following research questions: What are the major paradoxes linked to a formal mentoring programme for foreign-born women? How are these paradoxes linked to the mentees' job-seeking capabilities?

\section{Ethnography}

After successful access negotiations, the ethnographic research process began at the beginning of 2016. We chose a combination of participant observation and semi-structured interviews as the method for this part of the larger research project. First-hand knowledge of the programme participants' perceptions of the mentoring was crucial, and we therefore conducted personal interviews. The participant observation had a two-fold function: on the one hand it was a preliminary investigation in order to determine what questions are relevant in this context. On the other hand, it was a method to gain an 'outsider's' view of the mentoring interaction and combine it with how the participants themselves presented mentoring in their interviews (see e.g. Fangen 2005: 188-189). Participant observation enabled us to obtain an overview of what was happening in the group meetings and gain insights that would not necessarily surface in the interviews. Moreover, we presumed from the beginning that for practical reasons, all the mentors and mentees could not be interviewed, and participant observation was a way in which to include as many participants as possible.

The first mentoring group we observed started in the autumn of 2015, with 11 mentors and 11 mentees. The second observed group began in the autumn of 2016, with 17 mentors and 17 mentees. The programme consisted of a kick-off meeting, a mid-evaluation and a final meeting. During the eight months of the mentoring process, the dyads also met according to their own schedules, and kept in touch via, for example, email or Messenger.

In addition to the three mentoring meetings of each group, monthly joint 
gatherings were open to all the participants. These meetings, all held in Finnish, consisted of workshops or presentations given by visitors on themes such as entrepreneurship and recruitment processes. In the kick-off meeting, the mentors and mentees listened to a presentation on the principles of mentoring and signed a mentoring contract. This was a simple paper in Finnish consisting of the mentor's and the mentee's contact details and space to describe the goal of the mentoring in one or two sentences. The introductory text of the form also emphasised that the mentor's task was not to find a job for the mentee. All the materials, for example the slides of the speakers, job adverts and other interesting information, were emailed to the participants after the meetings.

The ethnography began with discussions with the organising NGO's employees and the observations of three of the joint meetings of the mentoring group, the purpose of which was to get to know the field in order to specify the research interests as well as build trust with the participants to facilitate later finding interviewees. In one of the joint meetings, the researcher presented the WeAll Project (Social and Economic Sustainability of Future Working Life Consortium) as a whole, explaining the aim of finding mechanisms of inequality. In these first meetings, the researcher did not write a field diary, but made notes after the meetings.

After the first group finished in the spring of 2016, all the participants were invited to an interview. We conducted 11 personal interviews with the women who had taken part in the first group as mentees (5), mentors (5) or organisers (1). These took place in the spring of 2016 and were supplemented at the beginning of 2017. The interviews lasted about one hour and were audio recorded and later transcribed verbatim by a professional transcriber. When they were contacted, and before recording began, the interviewees were informed that good research ethic guidelines, including anonymity and confidentiality, would be followed throughout the research process (see the National Advisory Board on Research Ethics 2009).

We introduce the interviewees by presenting some basic knowledge about them in the list of references. The pseudonyms are popular women's names in English. The mentors' pseudonyms begin with the letter $M$ and the mentees' names begin with the letter A, since the word aktori, 'actor' is used for mentee in Finnish language. 'Actor' highlights the expected active role of the mentee as the 'subject of the mentoring, the "apprentice or trainee", an active participant and the owner of the mentoring process' (Ahlfors et al. n.d., Kanniainen et al. 2017). Nevertheless, in the text we use the term mentee, as 'actor' in English already has several meanings.

All except one of the interviewed mentees were from different European countries, including western parts of Russia. Some of those who were from, for 
example, the Middle East, did not come forward to be interviewed. This could be due to the lack of a common language, because apart from Finnish, English was the only language offered in the interview invitation. The researchers did not define the level of education of the mentees: this was done by the NGO when the mentees were signed up for the programme. Three of the mentors had a Finnish background and two had a foreign, European background.

The interviews were semi-structured and included open-ended (Fägerborg 1999, Hennik et al. 2011) questions about the mentoring process and the mentoring programme, how the interviewee saw her future in Finnish working life, and what factors could hinder or help her in achieving her career goals. The themes were similar in both the mentees' and mentors' interviews. All the interviewees were asked to introduce themselves in their own words. We deliberately did not underline the interviewees' journey or reasons for coming to Finland, in order to keep the focus on working life.

Most of the interviews were conducted in Finnish. In the case of two mentees, the language was English, and in two other mentees' interviews, a mixture of languages was used. Many of the interviewees were very busy and the researchers were fortunate to be able to get an interview at all. The interviewer, a member of the research team, felt that even though the interviews were rather short, they were open and relaxed. Although they covered difficult issues, the atmosphere was positive, with joking and laughter.

The second mentoring group, which started in the autumn of 2016, was followed throughout its different phases. Our researcher took part in five meetings (of the seven in total), including the kick-off, the mid-evaluation and the final meeting in the spring of 2017. The researcher acted as a participant, except in the discussions of mentoring dyads in the first meeting. The form of ethnography used was active participation: the researcher sought to participate in many activities without being a mentor or a mentee herself (Hennik et al. 2011: 182). She presented the aims of the research in the kick-off meeting and the participants were given the option of declining to take part in the research. She explained that anonymity and confidentiality would be carefully adhered to throughout the project. The research team decided to also anonymise the NGO for the benefit of the participants.

\section{Paradox as a framework for the analysis}

In this study, we define a paradox as consisting of contradictory yet interrelated elements, which seem logical in isolation, but absurd and irrational when they appear simultaneously (Schad et al. 2016, Lewis 2000). Some researchers have emphasised the persistency of the contradiction between interdependent elements 
(Schad et al. 2016). For us, the key characteristic of a paradox is the simultaneous presence of contradictory, even mutually exclusive elements (Cameron \& Quinn 1988). For example, collaboration - competition tensions in organisations, or social mission - financial performance in social enterprises, have been identified as paradoxes (Schad et al. 2016).

In accordance with Quinn and Cameron (1988), we perceive a paradox as an ongoing process that reflects cyclical dynamics that can be either reinforcing or self-correcting (Sundaramurthy \& Lewis 2003). We do not perceive paradoxes as positive or negative as such. Instead we try to tap into the possibilities that the identification of paradoxes offers. We hope that 'coping with' or even 'working through' paradoxes will help us find ways of improving the mentoring of foreign-born women (see Schad et al. 2016).

The analysis was conducted in three stages, and we applied the paradox meta-theory framework generated by Schad et al. (2016). First, we identified the paradoxes in the sources through closely reading the interviews and field notes. At this stage, we identified and categorised tensions and examined the interplay between interdependent contradictions. Second, we chose two thematic 'clusters' - paradoxes that we assessed as most significant for the mentees' job-seeking and career capabilities. We selected the paradoxes for closer analysis on the basis of previous research on the employment of foreign-born women, especially in Finland. At this stage, we elaborated the analysis by stressing collective approaches and individual responses: the individual actors' capabilities, cognition and emotional responses.

In the third stage of the analysis, we aimed to find practical solutions for developing the career mentoring of foreign-born women, specifically in the Finnish context. In the meta-theory framework, this third stage includes deepening the understanding of the outcomes and the impact of the paradox, including its dynamics and cyclical processes which can both enable and constrain. In practice, these stages of the analysis were intertwining and cyclical, as the exploratory analysis had already started with a preliminary study and was further accelerated by stakeholder meetings. The stakeholder meetings took part throughout the journey of the analysis.

\section{Mentoring in an intercultural context}

Drawing on Eby's definition (2010: 505), we see mentoring here as 'a developmentally oriented interpersonal relationship that is typically between a more experienced individual (i.e., the mentor) and a less experienced individual (i.e. the protégé)'. We decided to use the term mentee since it better reflects our view of mentoring: instead of the more traditional idea of mentoring as a hierarchical relationship we think mentoring should be understood as a dialogue based on equ- 
ality, interaction and trust. The goal of the process is to meet the mentee's needs, and thus the mentee plays an active role in the dialogue (Law 2013). In an intercultural context, the participants benefit from cultural awareness, which includes cultural self-awareness and situation-specific awareness (Osula \& Irvin 2009). The development of intercultural competence demands self-reflective processes to encounter embedded stereotypes, fears and uncertainties, and thereby the tolerance of confusion and complexity - according to Holmes and O'Neill (2012: 717) it 'involves critical cultural awareness of Self and Other in an intercultural encounter, with appropriate attention to relationship building, monitoring and managing emotions, empathy, and facework'.

According to Kram's classic text (1983), the functions of mentoring tasks can be categorised as psychosocial and career enhancing. The psychosocial functions refer to the mentee's experience of self-image and capability being encouraged through role modelling, acceptance, counselling, friendship, and confirmation in the mentoring relationship. The career-enhancing functions refer to actions and activities through which the mentor provides the mentee with sponsorship and coaching, sets challenging assignments, and increases visibility to advance the mentee's career (Allen \& Eby 2004). Formal mentoring programmes, which have a systematic approach to mentoring and are frequently used by working life organisations, typically aim to advance the mentees' competences and career and enhance employee retention and workforce diversity (ibid., Eby \& Lockwood 2005). The programmes may involve training before and during the mentoring process to clarify both the mentor's and mentee's roles and responsibilities, and to make them feel comfortable with the mentoring process (Eby \& Lockwood 2005).

In mentoring research, a dominant interest has revolved around the advantages that mentoring provides participants (Eby et al. 2008, Gentry et al. 2008). For example, mentoring has shown to advance a mentee's self-efficacy, networking and job performance ratings (Kram 1983, Scandura \& Williams 2004, Mutanen \& Lämsä 2006, Lester et al. 2011). Furthermore, mentoring has the potential to also promote the mentor's career success and personal and job satisfaction (Kram 1983, Allen et al. 2004, Eby et al. 2008). Despite these various important benefits, it is essential to recognise that a mentoring relationship is an interpersonal relationship that is intensive by nature (Kram 1983). Various studies show that unpleasant, conflicting, unexpected and surprising events and outcomes also occur in such relationships (Eby et al. 2000). In general, researchers have largely ignored the negative aspects of mentoring (Scandura 1998, Eby et al. 2000). The 'dark side of mentoring' seems to have become a taboo subject in mentoring discourse (Scandura 1998). However, in line with Duck (1994), instead of a purely black and white division into the positive and negative characteristics of mentoring relationships, it is important to recognise their multiple and complex nature. 


\section{The language paradox}

The most conspicuous paradox in the mentoring programme was the use of Finnish language as the only 'official' language in the process. The paradox is that, even though learning Finnish was very important for the mentees, having Finnish as the only language in the programme also caused considerable problems for some of the participants. Learning the language of one's new home country is one of the most crucial skills needed for finding employment (Ahmad 2005, Eronen et al. 2014, Jaakkola \& Reuter 2007, Nieminen et al. 2015, Tarnanen \& Pöyhönen 2011). This is why the language of the mentoring programme was Finnish, despite the fact that some of the mentees did not yet have the skills to use the language in spoken and written forms in the depth required to communicate on issues crucial for working life. For some mentees, the language requirement evoked frustration and other negative emotions. In these contexts, we argue this is not favourable for learning and strengthening the professional self-assurance of the mentees.

The most notable language problems occurred in the joint meetings of the programme. The learning of Finnish and the level of language skills was a frequently discussed topic in these gatherings: the mentees were well aware of the importance of learning Finnish, and the topic kept arising in the discussions. The Finnish language skills of the mentees varied greatly. Some were fluent in speech but expressed a need for more advanced language courses that emphasise written language and details of grammar, since the language requirements in their desired jobs were high. Some other participants could not take part in the discussions at all, because it was difficult for them to understand the presentations of the guest speakers or the organisers, or to effectively follow the discussions. Some could understand most of what was said but found it very hard to express themselves in Finnish. A more critical notion would be to ponder why the reasons for the majority of mentees not taking part in discussions in the general meetings was not addressed. Were the organisers avoiding pressuring the mentees to talk? Was it due to the ideal of efficiency, common in working life in Finland (e.g. Niemi-Kaija 2014)? The visiting organiser's comment was pronounced and spontaneous and could thus be interpreted as an unconscious 'symptom' of the idea of status quo in the power relations (see Koskela 2013; Tuori 2009), maintaining the more knowledgeable and active 'helper' role of the organisers and mentors and passive role of the mentees as parties to be 'helped'. Behtoui et al. (2017) have concluded that in working life contexts, the racialised and less powerful tend to resort to silence rather than voice or exit.

Astrid, who has a $\mathrm{PhD}$ from her native country, explained she had difficulties with the language:

Astrid: Of course, I, it was very, very good that I had to eeh, [try to cope in Finnish] but it was tiresome also. Very fast I had to understand so- 
mething pretty clear [and] I couldn't. I had to have a tablet to translate it. It was multitasking and I am not a multitasker, I am not.

The need to use a tablet computer in order to translate while the speaker was already moving to the next topic felt troublesome and tedious, at least for Astrid. Very few of the interviewed women were as outspoken about their difficulties in understanding what was being said, but the problems were reflected in the general discussions of the joint meetings, in which the mentors and organisers took more part than the mentees. Despite her difficulties, Astrid felt the organisers had a positive attitude: she felt safe and 'could ask anything. She even went on to say that only in Finland can she feel so free in a meeting: people were joking and were free to say what they were thinking. Based on the ethnographer's experiences of the meetings, it seems fair to say that the participants felt safe. Most mentees left the gatherings with a hopeful mindset, even though they might not have understood everything that was said.

However, this was not always the case. In most meetings, there was time for all the mentees to tell the group how they were doing and what they were doing with their mentor. On one of these occasions, one mentee mentioned that she had felt very low after a mentor - not her own mentor - had said in the previous joint meeting that her Finnish skills were not good enough for the profession for which she had a university degree from her homeland. This incident was immediately identified as important by the researcher:

In principle, I agreed with the mentor, since the mentee's profession involves knowing details in complicated texts and being able to correctly find different interpretations of literary expressions. On the other hand, this mentee, like many foreign-born women I have met during the course of this research, underestimate the level of their language skills and are often too modest. Yet in this case the mentor had a point as regards the particular job the mentee was applying for. However, she expressed this view in such a blunt way that the mentee felt thoroughly dispirited and told us she left the meeting with tears in her eyes: 'In the last meeting there was a mentor who was sounding off that everyone needs to learn Finnish. I felt like going away to cry. Always the same thing, even here.' The strict language requirements felt particularly unfair, even cruel, in the light of the long waiting lists for language courses, and the lack of higher-level Finnish courses (Field note diary).

On one occasion, the organisers of the programme also pushed the use of Finnish to an extent that could have discouraged the mentees. In the kick-off meeting of 
the second observed mentoring group, the mentors and mentees had just met for the first time to get to know each other and discuss the process that was about to start.

The dyads had spread out in the venue of the first meeting. Two dyads stayed in the meeting room in which I was chatting with one of the organisers and a representative [of another NGO that offers a similar kind of mentoring] who had given a presentation at the beginning of the gathering. In the middle of our chat, this [other NGO's] expert shouted to the other end of the room where the two mentoring dyads were concentrating on the initial discussions, telling them to speak Finnish. The power relations were further highlighted by the fact that we were standing up and looking down at the mentoring dyads, sitting down in relaxed positions (Field note diary).

The suspense was discharged by one of the mentors replying with a serious expression that they had decided that using English was the best solution for now. The other dyad simply continued their discussions in English without even responding. The other NGO has stricter language requirements than this observed programme, which makes the expert's comment understandable. Language can only be learned if it is used and the learner should exploit every possibility to use it. However, in this programme, the language skills of the mentees differed greatly, and it was clear that some of the mentees were not able to carry out the programme in Finnish. The sudden requirement of speaking Finnish may thus result in some of the mentees feeling shut out - a result that is contradictory to the aim of the programme to promote the inclusion of the mentees in Finnish society. Therefore, this could be seen as a situation that contradicts everything that mentoring stands for.

In her interview, Ann questioned the emphasis on the use of Finnish language in the dyad. To her it was an inconvenience and made her career aspirations progress slower, even though she fully recognised the importance of learning Finnish. Ann said she was happy that she and her mentor could speak the same language: according to her, this made their discussions 'fast and more efficient'.

Ann: In my opinion, the person should be in the centre [of the process] so that it really moves forward.

Interviewer: So, the mentee should be in the centre?

Ann: Yes, she and her working life. Not learning the language. That will follow automatically, if she gets a job. 
In the one-to-one mentoring relationship, the dyads were able to choose ways in which to communicate more freely. Several mentoring dyads chose to speak English or another common (native) language, but some used Finnish throughout the process. Still, none of the interviewed mentees mentioned any improvement in their Finnish language skills as a result of the mentoring, although some said that the opportunity to practise Finnish was a positive thing. Myrtle described the challenges of working strictly in Finnish in the programme from a mentor's point of view.

She was aware of the importance of Finnish for the mentee but pointed out that teaching Finnish and the complex issues of job-seeking and careers at the same time was too great a task. She also questioned these strict language requirements. Implicitly, Myrtle highlighted that the over-ambitious language requirements had resulted in another disappointment and exclusion of at least one of the mentees who 'could not cope' and quit the mentoring process because she did not know enough Finnish. Myrtle brought up this criticism of the programme while talking about the tasks and the role of the mentor. She stated that the mentor's role is to listen to the mentee and respect their wishes throughout the mentoring process. She concluded that although it is possible to guide, you cannot force the mentee to do anything. By enforcing the use of Finnish in the mentoring process, the mentor also maintained her status as the more knowledgeable and competent member of the mentoring dyad.

Mollie, who is a professional career coach, decided to have the discussions with her mentee in English, but expected the mentee to provide some job-seeking related texts in Finnish. Mollie herself was from a Swedish-speaking family, and instead of pointing out the importance of Finnish, she emphasised that she hoped she could help her mentee identify her fields of expertise, her strengths and her potential, so that the she could then verbalise to employers who she is and what she is capable of. Mollie seemed to feel the need to apologise for her decision to use English in the discussions with her mentee but justified the language choice by saying that mentoring was much more effective this way. She highlighted that she wanted to start the dyadic process by enabling her mentee to assert her self-esteem. In Mollie's case, effectiveness can be seen as a culturally acceptable reason to use English instead of Finnish.

\section{The support paradox}

Despite the common instructions and the mentoring agreement signed by both mentor and mentee, the participants had varying expectations of the mentoring process and its implications. Some of these inconsistent expectations and practices can be seen as contradictory elements which we have compiled here as the 
support paradox. This paradox is based on the contradiction of the mentor taking an excessively enthusiastic role in the interaction: this enables and even encourages the mentee to take a passive, withdrawn role.

Several mentees highlighted that 'fixing' the mentee's $\mathrm{CV}$ was one of the mentor's most important tasks. In at least two cases, the mentor actually wrote up the mentee's $\mathrm{CV}$, although in most cases the mentor preferred to comment on the document, which the mentee improved and finalised herself. Improving a $\mathrm{CV}$ is indeed an important step and help from someone who is familiar with current recruitment processes can be a decisive factor in presenting the job-seeker in an effective way. Nevertheless, if the mentee herself is not the subject of the process but merely a receiver of a ready-made list of career details, she will still lack $\mathrm{CV}$-making skills after the mentoring process is over. This might even result in an awkward situation for the mentee if, in the recruitment process it emerges that she does not possess the word processing skills that were needed to make the $\mathrm{cv}$, for instance. Thus paradoxically, the much-needed help provided by the mentor does not always advance the mentee's capabilities and independence.

Some of the interviewed mentees had very high expectations of the mentoring process. They expected the mentor to be a professional from their own occupation, someone who could give them a job or at least a training position. For example, Alice had a positive attitude towards the mentoring but said it was too general for her. She wanted the mentor to concretely arrange a job for her, by for instance, inviting her for training or a work trial at her own workplace.

Alice: It would be good if the pair was made up from people who have the same profession or the same background or that the mentor already works in the institution where the mentee would like to work. Then, the mentor could invite the mentee for practical training or a work trial. That way, the mentee could practice first and build some networks too.

The mentoring contract states that it is not the mentor's task to find a job for the mentee - thus avoiding the mentee taking on the role of a 'protégée. In this sense, Alice's wish seems unrealistic, although organising training or the possibility of a work trial can be seen as different to finding a 'proper' job. Alice was the only mentee who said so openly that she expected this. She highlighted the importance of the mentor being, if possible, from the same occupation as the mentee. This was also the wish of other mentees and some mentors.

In practice, the organisers had very limited resources for trying to find mentors. Indeed, most of the mentoring dyads could be seen as practising 'general' career mentoring with overarching goals, as Mollie, Alice's mentor, described in the 
previous section. In her interview, Mollie said she was pleased to see Alice 'start to bloom' during the mentoring process. Mollie used blooming as a symbol for the process in which Alice's self-esteem grew through her increased self-knowledge. The paradoxical aspect here is that Alice might not have been able to utilise any opportunities provided by a mentor from her own occupation until she regained her self-assurance. This is a two-fold argument. Firstly, self-doubt after a longer period of unemployment can make it difficult to tell even someone with the same occupation about your skills and abilities. Sometimes an 'outsider' can also see the job-seekers' opportunities through a wider scope, not only within the shared occupation (which might not deliver as many possibilities, for instance, because of language requirements). Secondly, if the mentee is not sure what she wants from her working life or from the mentoring process, the mentor might not be able to help, whatever their occupation.

In two cases, the mentees had difficulties following 'assignments' such as amending their $\mathrm{Cv}$, in the way their mentors would have liked them to. One of these mentees fell ill during the mentoring process and another began to study. Nevertheless, they both blamed themselves explicitly for being lazy or implicitly for being incapable of meeting the requirements of the mentor and the job market. Observation of the group discussions made it clear that some mentees had mixed feelings about being helped by a mentor. Some said the mentor was the more active part of the dyad: they seemed to feel uncomfortable about this, as they knew that the mentee should actually be the carrier of the process. It remains unclear whether the professional background of the mentee had anything to do with the difficulties they experienced. Before becoming unemployed, both these interviewed mentees had years of experience in occupations in which they had worked as therapists. It is possible that part of their difficulties was born from the paradox of now being the helped instead of the helper. In some discussions with the mentors, a sense of disappointment emerged about the mentee not being more active and making the collaboratively planned changes to their $\mathrm{CV}$, for example. This mentee reluctance is in parallel with Colley's (2003) finding regarding the power of the mentee: the mentees were not passive recipients of mentor support, but exercised their own agency and resistance, although with contradictory results.

\section{Improving mentoring through a paradox analysis}

Through our analysis, we interpreted two paradoxes in the studied mentoring programmes: the language paradox, and the 'clustered' support paradox. Both paradoxes have cyclical dynamics which are easier to control when they are identified.

The detected language paradox maps out the enabling and restricting aspects of using Finnish as the only 'official' language in the studied programmes. Using 
the Finnish language fosters the improvement of the mentees' vital language skills. At the same time, when the mentee's Finnish language skills are somewhat deficient, the situation becomes constraining and can create a vicious circle of negative experiences for the mentee: negative experiences are harmful to the mentee's self-esteem, and this feeling of inadequacy may even force them to use the Finnish language which, in turn, causes further negative experiences. Culturally, the language paradox is based on the strong position of the Finnish language in Finland. Almost nine out of ten people in Finland speak Finnish as their first language. Finnish as a language is strongly connected to Finland becoming an independent state and, as in many other countries, there is a strong link between language and identity (e. g. Koivunen 2012). Fears about the extinction of Finnish are often currently expressed in the press. Based on this research, many 'immigrant' job-seekers are keen to learn Finnish (see also Nieminen et al. 2015, 54). In the mentoring process, talking about career goals, occupational skills or other complicated matters in another, situationally more functional, language should not be a concern. In line with Osula \& Irvin (2009), we suggest that especially in an intercultural context, the mentor should be careful when correcting the mentee or challenging their aspirations, to avoid questioning the security of their relationship.

Learning a new language is a complicated and multifaceted process. For an adult, it is a challenge that typically requires a great deal of time, practice, repetition, motivation, and opportunities to exercise the language (Perdue 1993: 254270, Sudhershan 2014). The Finnish language is exceptional compared to most of its neighbouring countries' languages and other European languages: its vocabulary is idiosyncratic and its structures are considered complex, making it relatively difficult to learn (Tarnanen \& Pöyhönen 2011). Learning a new language often requires intensity, which a mentoring relationship can rarely provide due to the fact that a mentoring dyad, as was the case in the studied programme, usually only meets once or twice a month. Thus, mentoring targeted at supporting job-seeking is not really a language course.

Based on the findings of this study, we suggest that to avoid a negative cycle, the organisers of mentoring programmes for foreign-born people should select the participants for the programme carefully: the required level of language skills should be defined beforehand and the participants' language skills should be evaluated before their recruitment. In addition, mentoring programmes such as that studied here would benefit from some practical educational tools that combine Finnish studies, knowledge of the Finnish labour market and job-seeking in Finland. For example, the participants may benefit from language learning tools that they could use independently at home, including inspiration for how to take advantage of surrounding learning material (websites, newspapers, books, podcasts, radio, television). 
Furthermore, the organisers could consider the possibility of including a person in the mentoring process who explains the principles and contents of mentoring to the participants in plain Finnish. A study by Lähdesmäki and Savela (2006) of immigrants' entrepreneurship training found that having a plain language Finnish instructor, in addition to a content teacher, was very useful for the participants. It increased their chances of understanding the teaching and the training programme gave them benefits for their entrepreneurial career. Since mentees with more advanced language skills might find this practice demotivating, testing the participants' language skills to ensure that they are at approximately the same level would eliminate this problem. In general, we believe that more research and practical elaboration of the advancement of various developmental methods in mentoring processes is needed. Digital technologies may offer solutions that could be further studied in the future (see, for instance, Velghe \& Blommaert 2014).

The support paradox is a cluster of aspects around the interplay between the mentor, the mentee and the mentoring programme itself. In this paradox, the mentee is positioned on the one hand as an object of the mentor's direction, help and instructions, which, according to Standing (1999), resembles the authoritative way of mentoring and emphasises the hierarchical relationship between a mentee and mentor. From this point of view, the studied mentoring programme may have a constraining effect on the mentee in the long run in terms of her development as an active and self-imposed job-seeker. Interestingly, in our study, both the mentee and the mentor used and expected this kind of mentoring which, being very instrumental (see Kram 1983) and ad-hoc by nature, may occasionally be helpful in a specific critical situation (for example, writing a $\mathrm{Cv}$ for the mentee). However, in the long run, this kind of relationship is problematic, because it does not effectively support the mentees' own learning and growth of her development and skills, which are crucial aims not only in the programmes studied but in mentoring processes in general (Kram 1983, Scandura \& Williams 2004, Eby \& Lockwood 2005, Eby 2010, Lester et al. 2011).

Culturally, the overpowering attitude of the mentor can be linked to the myth of 'the strong Finnish woman'. In addition to being physically and mentally strong (Koivunen 2003, Markkola 2002, Tuori 2009), especially during and after the Second World War, Finnish women were expected to accept great personal losses without showing grief in public, while at the same time public expressions of joy and happiness were also disapproved of due to the nation's losses (Koivunen 2003, Olsson 2011). The cultural practices of concealing one's feelings are still very much visible in, for example, national festivals and inexpressive international sport stars. In the context of mentoring, the combination of the ideas of being strong, fact-focused and not showing your feelings can sometimes result in bluntness, which can easily be interpreted as non-empathetic and unsupportive. 
On the other hand, in the support paradox, both the mentor and the mentee also position the mentee as an active subject in the relationship. Such a mentoring relationship refers to the empowerment and active development of the mentee as regards her skills and other capabilities (Lester et al. 2011). The mentoring literature labels this kind of orientation a caring relationship between the mentee and mentor (Colley 2003, Mutanen \& Lämsä 2006). Such a relationship can be regarded as a more enabling factor for the mentee's job-seeking than merely being given instructions on what to do.

In line with Lester and colleagues (2011), despite the argument that formal mentoring is not as efficient as informal mentoring (for example Eby \& Lockwood 2005), the results of our study indicate that formal mentoring can be helpful. It can support the mentee's - in this study, foreign-born, female mentees - capabilities to become more efficient and self-directed in job-seeking. Moreover, we think that formal mentoring programmes also present a way to include people other than officials in the process of 'integration', the mentors' networks making it more diverse and possibly more effective. It is possible that the positive results of the mentoring programmes here, as well as in general (Allen \& Eby 2004, Eby \& Lockwood 2005, Lester et al. 2011), may be linked to the proactivity of people who seek to take part in the programmes as mentees. Like the foreign-born women in this study, they are likely to be motivated and active, which generally helps them progress in working life. All in all, we suggest that despite its complex and paradoxical nature, formal mentoring has the potential to offer support that can boost the progress of foreign-born women in working life, specifically in job-seeking.

At the beginning of this article, we set ourselves the task of exploring the cultural practices and ideas visible in our sources in an 'intercultural' mentoring programme. Using the paradox frame as a lens, our interpretation is that the most significant cultural meanings were the over-emphasised focus on the Finnish language (the language paradox), and the myth of the strong Finnish woman (the support paradox). These can be seen to have aspects of both cultural awareness and situation-specific awareness (Osula \& Irvin 2009). Using situation-specific awareness, some mentors understood that it was best to break the rules of the mentoring programme and not use Finnish in all their communications, enabling a more equal setting for professional discussions. In some cases, when the mentors failed to use situation-specific awareness, the mentees felt even worse about their abilities and working life opportunities. Similarly, the myth of the strong Finnish woman can be an empowering and positive model for the mentee, but can have a negative impact on the mentor, enabling undercurrents in the mentoring discussions which may be perceived as harsh and even hostile. Instead of encouraging and supporting, this may result in undermining and 'othering' the mentee. 


\section{Acknowledgements}

This research was funded by the Strategic Research Council of the Academy of Finland, the Social and Economic Sustainability of Future Working Life (WeAll) Consortium (project number 292883). We would like to thank the editors and the anonymous reviewers of this article for their valuable comments.

Tytti Steel is a Postdoctoral Researcher at the Department of Cultures, University of Helsinki. Her research interests include working life and employment, especially from the point of view of minorities and people who have difficulties in finding employment. She works in an Academy of Finland (Strategic Research Council) funded research project (WeAll) on socially and economically sustainable future working life. E-mail: tytti.steel@helsinki.fi

Anna-Maija Lämsä is Professor of Human Resource Management and Vice Dean at the University of Jyväskylä, School of Business and Economics, Finland. Her research interests are organizational and leadership ethics, and equality and diversity in organizational life. Her research is published widely both internationally and nationally. She is currently co-director and principal investigator in the program Equality in Society (WeAll No. 292 883) by strategic research funding of the Academy of Finland.

Marjut Jyrkinen is Associate Professor in Working Life Equality and Gender Studies, University of Helsinki, and director of research consortium on sustainable working life (weallfinland.fi), funded by the Strategic Research Council at the Academy of Finland. Jyrkinen has studied gendered violence and violations in and outside organizations, leadership, and gendered ageism. Her latest book, with Elina Penttinen and Elisabeth Wide, is Emotional Workplace Abuse: A New Research Approach, published in 2019 by Palgrave MacMillan.

\section{Notes}

${ }^{1}$ We use the words migrant and foreign-born as synonyms to a person with foreign background, as defined by the Statistics Finland (http://www.stat.fi/meta/kas/ulkomaalaistaus_en.html).

${ }^{2}$ In a previous project analysing interviews of female refugees (Steel $\&$ Tuori 2016), it became clear that focusing on the journey to Finland and immigrant identity moves the emphasis away from working life issues.

${ }^{3}$ For more on the fluid boundaries of analysis in research processes see, for instance, O'Dell \& Willim 2011.

${ }^{4}$ Finland has two main national languages: Finnish (88,3\%) and Swedish (5,3\%); offi- 
cial minority languages are three variants of Sami, Romani, Finnish Sign Language, and Karelian. The most spoken other languages are Russian, Estonian, English, and Arabic.

\section{Interviews}

The audio recordings and transcriptions of the interviews and the field notes are currently in the possession of the WeAll Research Consortium at the University of Helsinki. In the future, the anonymised transcriptions will be archived in the Finnish Science Data Archive.

\section{Presentation of interviewees}

\begin{tabular}{|l|l|l|l|}
\hline Pseudonym & Age group & Background & Job market situation \\
\hline Alice & $30-39$ & European & Pay subsidy job \\
\hline Ann & $50-59$ & European & Entrepreneur and job-seeker \\
\hline Astrid & $40-49$ & European & $\begin{array}{l}\text { Job-seeker with a few hours of } \\
\text { work per week }\end{array}$ \\
\hline Audrey & $50-59$ & South-American & Pay subsidy job \\
\hline Ava & $50-60$ & European & Studying \\
\hline Mary & $50-59$ & European & Full-time employment \\
\hline Melanie & $30-39$ & Finnish & Full-time employment \\
\hline Mia & $20-29$ & European & Full-time employment \\
\hline Mollie & $60-69$ & Finnish & Entrepreneur \\
\hline Myrtle & $60-69$ & Finnish & Retired \\
\hline Nancy & $40-50$ & Finnish & Full-time employment (NGO) \\
\hline
\end{tabular}

* other than Finnish; by European we mean the geographical area of Europe including western parts of Russia 


\section{Culture Unbound}

Journal of Current Cultural Research

\section{Literature}

Aalto, Maria, Liisa Larja \& Karmela Liebkind (2010): Syrjintä työhönottotilanteissa: tutkimuskatsaus. Työ- ja elinkeinoministeriön julkaisuja, Työ ja yrittäjyys 16/2010. Helsinki: Ministry of Employment and the Economy.

Ahmad, Akhlaq (2005): Getting a Job in Finland: The Social Networks of Immigrants from the Indian Subcontinent in the Helsinki Metropolitan Labour Market. Research Reports No. 247, Department of Sociology. Helsinki: University of Helsinki.

Ahlfors, Gunta, Inka Saarela, Sari Vahanen \& Marina Wetzer-Karlsson (N. d.): Työuramentoroinnilla tuloksiin. Helsinki: Väestöliitto.

Allen, Tammy D. \& Eby, Lillian T. (2004): "Factors related to mentor reports of mentoring functions provided: Gender and relational characteristics." Sex Roles, 50(1/2), 129-139.

Allen, Tammy D., Lillian T. Eby, Mark L. Poteet \& Lizzette Lima (2004): “Career Benefits Associated with Mentoring for Protégés: A Meta-Analysis.” Journal of Applied Psychology, 89(1), 127-136.

Behtoui, Alireza, Kristina Boréus, Anders Neergaard, Soheyla Yazdanpanah (2016): "Speaking up, leaving or keeping silent: racialised employees in the Swedish elderly care sector." Work, employment and society, Vol 31(6), 954-971.

Bhabha, Homi K. (1994/2003): The Location of Culture. London: Routledge.

Cameron, Kim S. \& Robert E. Quinn (1998): "Organizational paradox and transformation." Robert E. Quinn \& Kim S. Cameron (Eds.) Paradox and transformation: Toward a theory of change in organization and management, 1-18. Cambridge, M.A: Ballinger.

Casado-Lumbreras, Cristina, Ricardo Colomo-Palacios, Pedro Soto-Acosta \& Sanjay Misra (2011): "Culture dimensions in software development industry: The effects of mentoring." Scientific Research and Essays, 6(11), 2403-2412.

Colley, Helen (2003): Mentoring for Social Inclusion: a critical approach to nurturing mentor relationships. London: RoutledgeFalmer.

Cooper, Peter A. (1993): "Paradigm Shifts in Designed Instruction: From Behaviorism to Cognitivism to Constructivism." Educational Technology 33:5, 12-19.

Duck, Steve (1994): "Strategems, spoils, and a serpent's tooth: On the delights and dilemmas of personal relationships." William R. Cupach \& Brian H. Spitzberg (Eds.), The dark side of interpersonal communication. Hillsdale, NJ: Erlbaum, 3-24.

Eby, Lillian T. (2010): "Mentorship." Sheldon Zedack (Ed.), APA handbook of industrial and organizational psychology. Washington, D.C.: American Psychological Association, 505-525.

Eby, Lillian T. \& Angie Lockwood (2005): "Protégés and mentors' reactions to paticipating in formal mentoring programs: A qualitative investigation." Journal of Vocational Behavior, 67, 441-458

Eby, Lillian T., Stacy E. McManus, Shana A. Simon \& Joyce E. A. Russell (2000): "The protege's perspective regarding negative mentoring experiences: The development of a taxonomy." Journal of Vocational Behavior, 57, 1-21.

Eby, Lillian T., Tammy D. Allen, Sarah C. Evans, Thomas Ng \& David L. Dubois (2008): "Does mentoring matter? A multi-disciplinary meta-analysis comparing mentored and non-mentored individuals." Journal of Vocational Behavior, 72, 254-267.

Elmgren, Ainur (2016): "Förfinskandet av Finland." Mats Wickström \& Charlotta Wulff (eds.) Mångkulturalitet, migration och minoriteter I Finland under tre sekel. Helsinki: The Society of Swedish Literature in Finland, 319-354.

Eronen, Antti, Valtteri Härmälä, Signe Jauhiainen, Hanna Karikallio, Risto Karinen, Antti Kosunen, Jani-Petri Laamanen \& Markus Lahtinen (2014): Maahanmuuttajien työllistyminen: Taustatekijät, työnhaku ja työvoimapalvelut. Työ- ja elinkeinominis- 


\section{Culture Unbound}

Journal of Current Cultural Research

teriön julkaisuja. Työ ja yrittäjyys. 6/2014. Helsinki: Työ- ja elinkeinoministeriö.

European Agency for Fundamental Rights (2018): Being Black in the EU: Second European Union Minorities and Discrimination Survey. Luxemburg: Publications Office of the European Union.

Fangen, Katrine (2005): Deltagande observation. Malmö: Liber.

Fägerborg, Eva (1999): 'Intervjuer.” Lars Kaijser \& Magnus Öhlander (Eds.) Etnologiskt fältarbete. Lund: Studentlitteratur, 55-72.

Gentry, William A., Todd J. Weber \& Golnaz Sadri (2008): "Examining career-related mentoring and managerial performance across cultures: A multi-level analysis." Journal of Vocational Behavior, 72, 241-253.

Hennik, Monique, Inge Hutter \& Ajay Bailey(2011): Qualitative Research Methods. London: Sage.

Holmes, Prue \& Gillian O’Neill (2012): "Developing and evaluating intercultural competence: Ethnographies of intercultural encounters." International Journal of Intercultural Relations, 36, 707-718.

Jaakkola, Magdalena \& Anni Reuter (2007): "Maahanmuuttajanaiset entisen Neuvostoliiton alueelta: Resurssit ja sijoittuminen työmarkkinoille." Tuomas Martikainen \& Marja Tiilikainen (Eds.) Maahanmuuttajanaiset: Kotoutuminen, perhe ja työ. Väestöntutkimuslaitoksen julkaisusarja D 46/2007. Helsinki: Väestöliitto, The Family Federation of Finland, 335-358.

Kanniainen, Minna-Rosa, Nylund, Jaana \& Kupias, Päivi (2017): Workbook for Mentoring. Helsinki: University of Helsinki.

Kent, Andrea M., Frances Kochan \& Andre M. Green (2013): "Cultural influences on mentoring programs and relationships: a critical review of research", International Journal of Mentoring and Coaching in Education, Vol. 2 No. 3, pp. 204-217. https://doi.org/10.1108/IJMCE-08-2013-0047

Kinnunen, Sari (2013): Womento: Koulutettujen Suomeen muuttaneiden naisten kokemuksia työuramentoroinnista. Helsinki: Metropolia Ammattikorkeakoulu.

Knuuttila, Seppo (1996): "Yhtenäiskulttuuri kansallisena kertomuksena". In Pekka Laaksonen \& Sirkka-Liisa Mettomäki (eds.) Olkaamme siis suomalaisia. Helsinki: Finnish Literature Society, 166-175.

Koivunen, Anu (2003): Performative Histories, Foundational Fictions. Gender and Sexuality in Niskavuori Films. Studia Fennica Historica 7. Helsinki: Suomalaisen Kirjallisuuden Seura.

Koivunen, Anu (2012): "Kansa liikkeessä." Anu Koivunen (ed.) Maailman paras maa. Suomalaisen Kirjallisuuden Seuran Toimituksia 1362, Tieto. Helsinki: Finnish Literature Society, 7-27.

Koskela, Kaisu (2013): "Boundaries of Belonging: Highly Skilled Migrants and the Migrant Hierarchy in Finland." Journal of Finnish Studies Vol. 17, No. $1 \& 2$ (Dec 2013), 19-41.

Kram, Kathy E. (1983): "Phases of the mentoring relationship." Academy of Management Journal, 26, 608-625.

KVINFO website http://kvinfo.org/ (Accessed 21 July 2017)

Kyhä, Henna (2006): "Miksi lääkäri ei kelpaa lääkäriksi? Korkeakoulutetut maahanmuuttajat Suomen työmarkkinoilla." Aikuiskasvatus, 26(2), 122-129.

Law, Ho (2013): The Psychology of Coaching, Mentoring and Learning. Malden, MA: John Wiley \& Sons Inc.

Lester, Paul B., Sean T. Hannah, P. D. Harms, Gretchen R. Vogelgesang \& Bruce J. Avolio (2011): "Mentoring impact on leader efficacy development: A field experiment." Academy of Management Learning \& Education, 10(3), 409-429.

Lewis, Marianne W. (2000): "Exploring Paradox: Toward a More Comprehensive Guide." The Academy of Management Review, Vol. 25, No. 4 (Oct 2000), 760-776.

Lähdesmäki, Merja \& Terttu Savela (2006): Tutkimus maahanmuuttajien yrittäjyyskoulutuksen vaikuttavuudesta: Case Pro Maahanmuuttajayrittäjä-koulutus. Oulun 


\section{Culture Unbound}

Journal of Current Cultural Research

seudun ammattikorkeakoulu \& Siirtolaisuusinstituutti.

Markkola, Pirjo (2002): "Vahva nainen ja kansallinen historia." Tuula Gordon \& Katri Komulainen \& Kirsti Lempiäinen (eds.), Suomineitonen hei! Kansallisuuden sukupuoli. Tampere: Vastapaino. 75-90.

Mutanen,Sanna \& Lämsä, Anna-Maija (2006): "Mentoroinnin merkitykset naisten urakehitykselle." Hallinnon tutkimus 25(2006):4, 19-32.

National Advisory Board on Research Ethics (2009): Ethical principles of research in the humanities and social and behavioural sciences and proposals for ethical review. http://www.tenk.fi/en/tenk-guidelines (Accessed 21 July 2017).

Niemi-Kaija, Kristiina (2014): Kokemuksellisuus työelämässä organisaatioestetiikan viitekehyksessä: työntekijöiden subjektiiviset konstruktiot tehokkuudesta. Jyväskylä Studies in Business and Economics 153. Jyväskylä: Jyväskylän yliopisto.

Nieminen, Tarja, Hanna Sutela \& Ulla Hannula (2015): Ulkomaista syntyperää olevien työ ja hyvinvointi Suomessa 2014. Helsinki: Tilastokeskus.

O’Dell, Thomas \& Robert Willim (2011): "Composing Ethnography.” Ethnologia Europaea $41: 1,27-40$.

OECD (2018): Working Together: Skills and Labour Market Integration of Immigrants and their Children in Finland. Paris: OECD Publishing. https://doi. org/10.1787/9789264305250-en

Olsson, Pia 2011: Women in Distress: Self-understanding among 20th-century rural women. European Studies in Culture and Policy. Vol 11. Wien: LIT Verlag.

Osula, Bramwell \& Steve M. Irvin (2009): "Cultural Awareness in Intercultural Mentoring: A Model for Enhancing Mentoring Relationships." International Journal of Leadership Studies, Vol. 5 Issue 1, 37-50.

Perdue, Clive (ed.) (1993): Adult Language acquisition: cross-linguistic perspectives. Written by members of the European Science Foundation project on adult language acquisition. Volume II: The results. Cambridge: Cambridge University Press.

Petrovic, Milica 2015: Mentoring practices in Europe and North America: Strategies for improving immigrants' employment outcomes. Brussels: King Baudouin Foundation.

Povrzanović Frykman, Maja (2012): “Struggle for Recognition: Bosnian Refugees' Employment Experiences in Sweden." Refugee Survey Quarterly, Vol. 31, No. 1, 54-79.

Scandura, Terri A. (1998): "Dysfunctional mentoring relationships and outcomes." Journal of Management, 24, 3: 449-467.

Scandura, Terri A. \& Williams, Ethlyn A. (2004): "Mentoring and transformational leadership: The role of supervisory career mentoring." Journal of vocational behavior 65:3, 448-468. https://doi.org/10.1016/j.jvb.2003.10.003

Schad, Jonathan, Marianne W. Lewis, Sebastian Raisch \& Wendy K. Smith (2016): "Paradox Research in Management Science: Looking Back to Move Forward." The Academy of Management Annals, 10:1, 5-64.

Standing, Mooi (1999): "Developing a Supportive/Challenging and Reflective/Competency Education (SCARCE) mentoring model and discussing its relevance to nurse education." Mentoring and Tutoring 6 (3) 3-17.

Statistics Finland (2019): Concepts, foreign background http://www.stat.fi/meta/kas/ ulkomaalaistaus en.html (accessed 27 June 2019).

Steel, Tytti \& Tuori, Annamari (2016): "'Olenko minä niin eksoottinen?': Pakolaistaustaisten naisten työelämään liittyvä identiteettityö.” Elore 23:2, 1-25.

Sudhershan, Aleksandra (2014): "E-Portfolio Self-Assessment of Intercultural Communicative Competence: Helping Language Learners to Become Autonomous Intercultural Speakers.” Barbara Geraghty \& Jean E. Conacher (Eds) Intercultural Contact, Language Learning and Migration, 150-165. London: Bloomsbury.

Sundaramurthy, Chamu \& Lewis, Marianne (2003): "Control and Collaboration: Paradoxes of governance." Academy of Management Review 2003, Vol. 28, No. 3, 
$397-415$.

Tarnanen, Mirja \& Pöyhönen Sari (2011): "Maahanmuuttajien suomen kielen taidon riittävyys ja työllistymisen mahdollisuudet." Puhe ja kieli 31:4, 139-152.

The Family Federation of Finland, Womento avaa uusia väyliä koulutettujen maahan muuttaneiden naisten työllistymiseen. http://www.vaestoliitto.fi/monikulttuurisuus/?x29403=2036985 (Accessed 19 July 2017).

Tuori, Salla (2009): The Politics of Multicultural Encounters: Feminist Postcolonial Perspectives. Turku: Åbo Akademi University Press.

Velghe, Fie \& Jan Blommaert (2014): "Emergent New Literacies and the Mobile Phone: Informal Language Learning, Voice and Identity in a South African Township.” Barbara Geraghty \& Jean E. Conacher (Eds) Intercultural Contact, Language Learning and Migration, 89-111. London: Bloomsbury.

Wolanik Boström, Katarzyna \& Magnus Öhlander (2011): "Polska läkare i Sverige: Om läkarroll, status och kulturella processer." Socialmedicinsk tidskrift 3/2011, 273-281. 